\title{
INNOVATIVE DESIGN CONCEPTS FOR QUALITY HPO ORGANIZATIONS
}

\author{
Srdjan Tomic ${ }^{3}$ \\ Jelena Rajković ${ }^{4}$ (iD
}

DOI: https://doi.org/10.31410/LIMEN.2020.231

\begin{abstract}
The business of organizations, in the conditions of globalization, radically changes the market, conditions, and strength of competition, requiring managers to change the way they react and solve problems using quality. The most successful business entities become those who continuously encourage creativity and create new knowledge. In order to be competitive in an uncertain and unpredictable market, high-performance organizations must be innovative, generating new knowledge and new technologies. These are organizations that, by managing quality, have the ability and skills of continuous recognition of challenges and changes.

The paper is based on showing how an organization needs to manage change and apply concepts, methods, and techniques that can pave the way for us to design OVP. The concept of a synergistic approach to the design of OVP organizations is necessary for an unpredictable and uncertain global environment.
\end{abstract}

Keywords: (HPO) organization, Market, Quality, Competition, Globalization.

7 The concept of "organizational transformation" gained importance in the theory and practice of management during the eighties and nineties of the XX centuries. Accelerated changes affect discontinuities in many industries. Faced with such challenges, organizations cannot be successful if they use incremental change. Organizations need major, radical - transformational changes. This is the way to create and design OVP organizations. (Ansof, 1990.p.384)

Figure 1. Organizational learning and changes in the environment

ORGANIZATIONAL LEARNING > ENVIRONMENT CHANGES

- Setting goals Vision,
- Education
- Feedback systems
- Development

School of Engineering management, Bulevar Vojvode Mišića 43, Belgrade, Serbia School of Engineering management, Bulevar Vojvode Mišića 43, Belgrade, Serbia 
Figure 2. Examining the philosophy of the organization

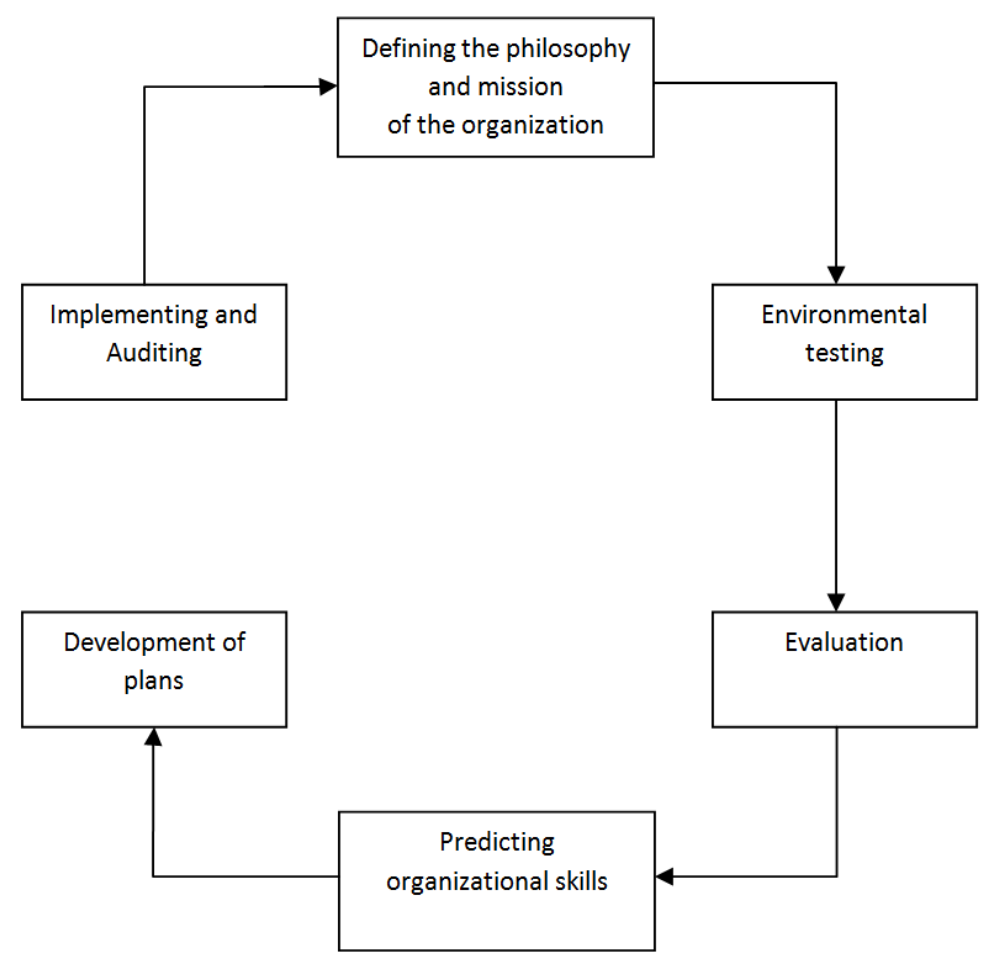

Transformational change must be supported by appropriate change processes (Bennis, 1997.p. 223).

Figure 3. Transformational changes

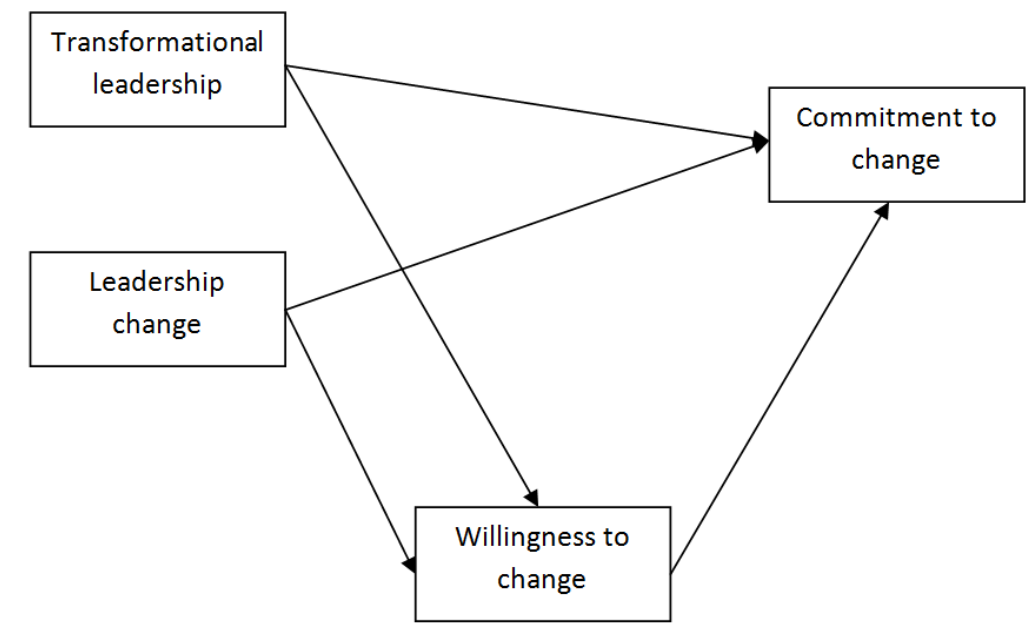

In a discontinuous, turbulent environment, it is not always easy to recognize the driving forces of change identify important strategic issues, and use the right critical success factors in decision-making. The characteristics of a turbulent environment are: growth is impossible to extrapolate, earlier strategies become unreliable, profitability is not accompanied by an increase in business activity, and the future becomes uncertain. (Certo, 2000, p. 128) A planned approach to such a situation is necessary to assess the effects of the enterprise. Based on that, it is possible to define a planned response and choose a way that has a positive effect on the achievement of the company's business goals (Deming, 1996, p. 254). 
Figure 4. Breakdown into linking organizational tasks

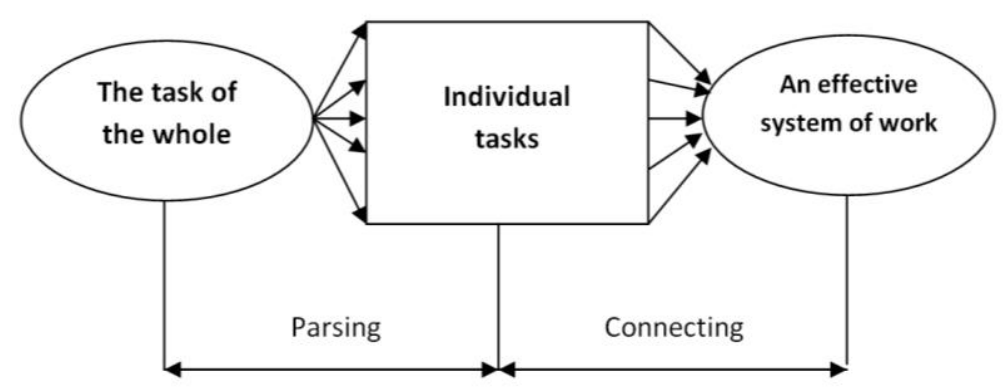

The causes of transformation processes in the literature are most often stated:

- increasing the globalization of business,

- acceleration of the rhythm of change,

- increasing the level of competition,

- variability of technologies (especially information),

- an increasingly diverse workforce,

- the transition from industrial to the knowledge society,

- market instability and economic conditions,

- quality and innovation as a managerial imperative,

- increase in demand by stakeholders,

- an increasingly complex managerial environment (Drucker, 1993, p. 198).

It is quite certain that the business of a company in conditions of discontinuity requires a reexamination of the current theory of business. P. Drucker states that business theory has three essential parts that must be at the heart of management:

- Assumptions about the company's environment,

- Assumptions about the specific mission of the company,

- Assumptions about the core (essence) of competence needed to accomplish an organizational mission (Kotter, 1998, p. 214).

The organization must continuously create new ways of competitive advantage. Therefore, incremental changes are insufficient, and changes of a transformational character are required.

Figure 5. Competitive advantage

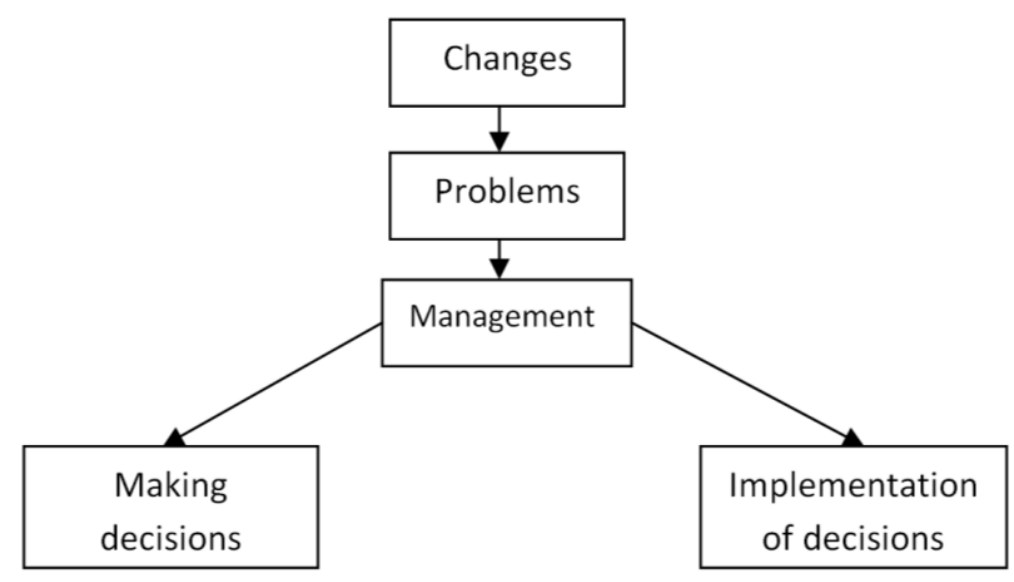


Figure 6. Discontinuous change

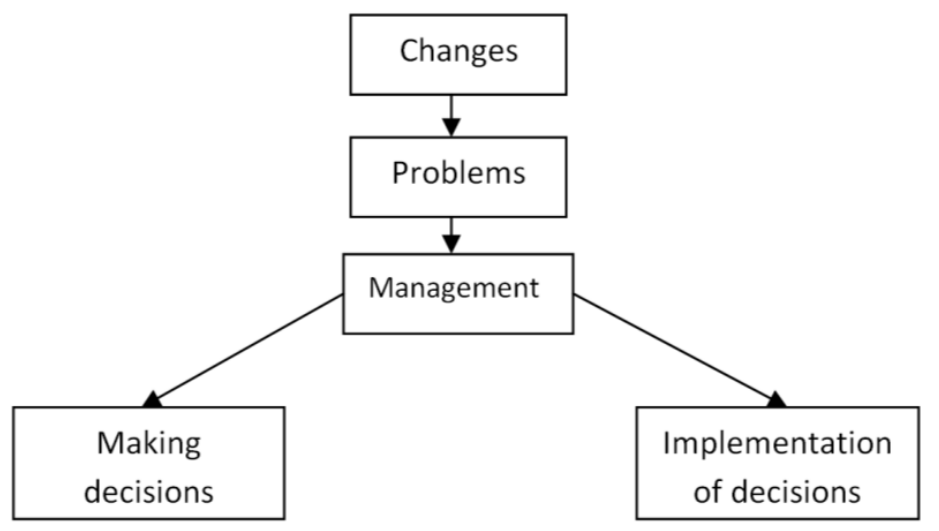

"Cotter suggests new rules that companies that want to be successful should follow. First, not relying on conventions, how profits were made in the twentieth century do not yield more results. Secondly, it is necessary to monitor globalization and its effects; everything is changing, offering new opportunities and gambling. Third, move towards a smaller and entrepreneurial, and away from a large and bureaucratic company. Speed and flexibility bring success in a changing world. Fourth, help large businesses outside the company, using consultants and others who offer new opportunities. Fifth, it is not enough just to have management, but also leadership to achieve success. Sixth, many jobs allow companies to show their willingness. Seventh, it is necessary to increase the ability to compete; to have high standards, as well as the desire to win is important both now and in the future. Eighth, never stop trying to ensure growth, and lifelong learning becomes increasingly important for business success." (Cotter, 2001, p. 256)

Organizations that want to be successful must be so-called "Innovative organizations" and "learning organizations".

Figure 7. Innovative organizations

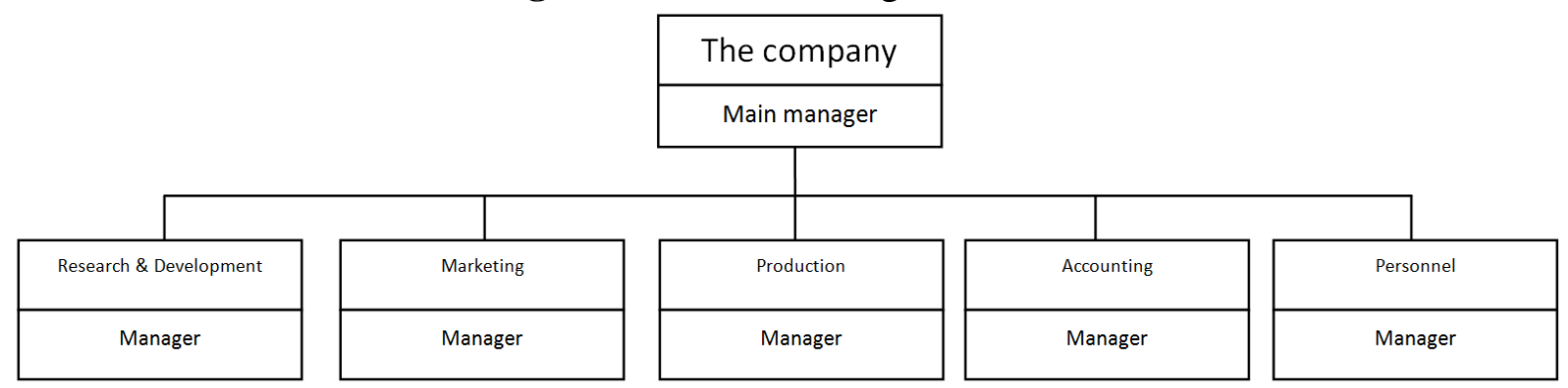

Figure 8. Adaptive changes

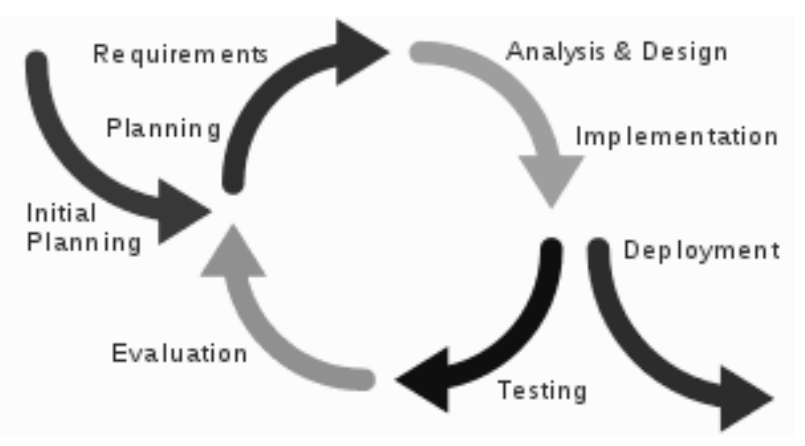


Changes are not welcome and they are avoided, and when a reaction is necessary, the action is aimed at preserving the existing situation. The solution to the problem is fragmentary and the first satisfactory solution is accepted. These changes do not change the key components of the company. They have a low level of innovation in the organization because they change the peripheral components of the organization that are not crucial for its identity, survival, and development.

The discontinuous equilibrium model is based on the assumption that changes in the environment in their frequency, extent, and level of turbulence exceed a framework that can be filled by adaptation through constant incremental changes (Stoner, 2002, p. 251).

This model of change does not include cumulative change. Radical changes are independent of incremental ones. The assumption of equivalence does not apply here. In terms of organizational learning, the broken balance model includes both adaptive and generative learning.

\section{TRANSFORMATIONAL LEADERSHIP VS CHARISMATIC LEADERSHIP}

"A charismatic leader transforms the needs, values, and aspirations of followers from personal interests to common interests. They enable followers to become very willing to personally commit and sacrifice for the realization of the leader's mission and to work beyond what is their obligation. The assessment is that charismatic leadership differs from other types of leadership based on the following factors by a set of behaviors, a set of personal traits, specific perceptions and attributes attributed by followers, and specific effects on followers (Williams, 2010, p. 362).

Charismatic leadership is possible under certain conditions:

- the beliefs of the followers must be similar to those of the leader,

- unconditional acceptance and commitment to the leader,

- members of the group or organization must be willing to listen to the leader,

- the emotional involvement of the group or organization in the mission of the charismatic leader and their own goals,

- the strong desire of followers to identify with the leader,

- leaders must use personal power and successful persuasion,

- followers attribute charisma to leaders who possess self-confidence, self-confidence, and enthusiasm.

Transformational leaders arouse interest in company transformation, inspire and encourage employees to focus on change. All employees must understand that incremental improvements will not lead to the desired state and that transformation as a basic qualitative change is of great importance for increasing the competitiveness of the company.

Resistance to change in many cases is not ignorance and misunderstanding of the need for change. This is a normal reaction of employees who want to protect some of their interests that they assume are threatened by change. It is often considered that change is not necessary or necessary; but that the situation is not favorable to start changes and that the costs of change are too high to the possible effects. 
Figure 9. Transformational leadership - types of leaders

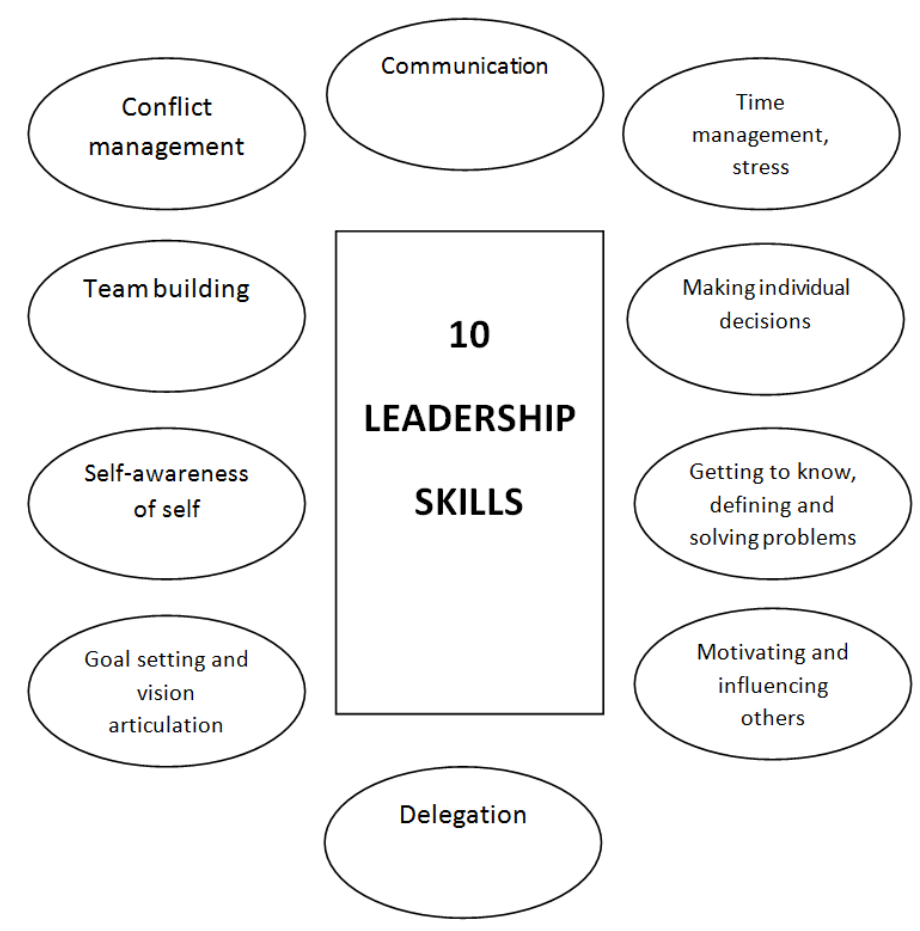

The process of transformation is the change of the company from what it is to what the leader wants to be. Transformational leadership is a complex and difficult task. A transformation leader has a clear vision of the future state of his organization. He is a kind of social architect of his organization, he creates trust among associates by making his position clear and maintaining it throughout the entire transformation process. He is a strong role model for his associates. He not only creates a vision but is also an actor of change (Živković, 2008, p. 278).

\section{CONCLUSION}

In a changing environment, an organization cannot achieve a competitive advantage if it relies solely on market strategy or strategic management of available resources. DSNA organizations must necessarily accept the importance of innovations creating ideas and knowledge and expand it through situational strategy, as part of the company's strategy. They also need to gather and develop new knowledge through creative methods and thus build new skills in order to achieve sustainable competitive advantage.

The situational approach or as many authors still call it the "contingent approach" or the uncertainty approach occurs in parallel with the growing changes in the organization environment. The contingent approach emphasizes that there is no "best way", but the way of organizing depends on the specific situation.

In the comparison of the systemic and situational approach, certain differences can be noticed. The system approach has developed a model of the organization as an open, complex, dynamic, and organic system, which contains general frameworks for understanding all organizations. A systems approach is a way of thinking about organizational variables and relationships. The situational approach concretizes the application of the system concept in specific conditions. 


\section{REFERENCES}

Ansof, H. I., Edward, J. McDonnell, Implanting Strategic Management, Prentice Hall, 1990., p. 384

Bennis W. and Mische M., The 21st-century organization: reinventing trough reengineering, Jossey-Bass Publishers, San Francisco 1997.

Certo C. S., Modern Management, 8th edition, Prentice Hall, Upper Saddle River N. J. 2000.

Deming, W. E., Kako izaći iz krize, Grmeč - Privredni pregled, Beograd 1996.

Drucker, P. F., Post- capitalist Society, Butterwort-Heinemann, 1993

Kotter, P., J., Vođenje promene, Želnid, Beograd 1998

Kotter, P., J., Cohen D., S., The Hart of Change, Harvard Business School Press 2001.

Robbins P. S. Organizational Behavior, seventh edition, Prentice Hall, Englewood Cliffs, NJ 1996.

Stoner A. F, R. Edvard Friman, Danijel R. Gilbert, Jr, Menadžment, Želnid, Beograd 2002.

Williams C., Principi menadžmenta, Data status, Beograd 2010.

Živković S., Strategijski menadžment- upravljanje transformacionim promenama, Alfa univerzitet, FTB, Beograd. 2008. 